\title{
Emilia Pardo Bazán, an Ethical Writer
}

\author{
DOLORES THION SORIANO-MOLLÁ
}

\begin{abstract}
Within the cultural context of nineteenth-century Spain, Emilia Pardo Bazán uses literature to raise public awareness on the death penalty. Considering the seriousness of the issue, she thought that emotions - not reason - could allow people to have a better understanding and to form their own opinion. Thus, in La piedra angular, through the fictional word of Marineda, she examines the controversies linked to the legal, human, and moral legitimacy of capital punishment and to the figures of both the criminal and the executioner, but also to the nature of truth and public opinion.
\end{abstract}

Keywords: Emilia Pardo Bazán; ethical writer; La piedra angular; death penalty; executioner; determinism; public opinion

Emilia Pardo Bazán (1851-1921) was a writer committed to the society of her time. Not only did she play an important role through her columns in the newspapers and her books, but also as a literary critic in various fields and cultural circles. She introduced new ideas that circulated in Europe in Spain, but she did so not from a purely artistic point of view. Her issues ranged from the feminine condition to education, travelling, sanitation, war, and politics, including technological and scientific breakthrough. They were all introduced to the readers from her own personal and critical point of view.

One ought to remember that at the end of the nineteenth century there were major developments in the fields of Medicine, Sociology and Law. As a result, one of the consequences was that issues such as human rights, criminology and the death penalty were given fresh consideration. The death penalty, for instance, became a topical issue rallying as many defenders as opponents, and Emilia Pardo Bazán could not help dealing with it in her writings.

From a legal point of view, the death penalty is the greatest form of punishment that can be inflicted on human beings since it deprives them of their lives. During the $19^{\text {th }}$ century, concepts such as civilisation, evolution and progress were used to question the right of a government to kill people. In this context, the articles and tales Emilia Pardo Bazán published in the press and her novel La piedra angular (1891) brought sufficient evidence of her commitment to this issue. The plot of novel is set in Marineda (La Coruña). It deals with a passion 
THION SORIANO-MOLLÁ

crime but it largely differs from a crime novel, despite the fact that a man in brutally killed by his wife and her lover and the murderers are arrested, tried and sentenced to death. The plot involves other characters, such as the public executioner Juan Rojo and the philanthropic doctor Pelayo Moragas. In the little conservative town, Juan Rojo is a despised and rejected for his profession. Being unable to endure this social underestimation, his wife abandoned him and their son, Telmo. As a passionate adept of psychological sciences and a firm opponent of capital punishment, doctor Moragas tries to understand the situation and help its victims. Moragas has a plan to save Juan Rojo and his son. He seeks to persuade Rojo to refuse to execute the criminals sentenced to death. If Juan Rojo accepted the proposal, the doctor, in return, would grant education to Telmo, taking the child to his home. For Moragas it is the best way to prevent execution and to help this poor and marginal people. Despite that, Juan Rojo ended up committing suicide because he could not bear the solitude without his son or failing to his duty as an executioner.

In Marineda, the crime provoked citizens' opposite reactions. There was a conflict between two lawyers, Cáñamo, a conservative man, and Febrero, a modern social criminalist. In this scenario the philanthropic doctor as well as the voices of the marinedinos or the public opinion were involved. The writer does not focus as much on the fulfillment of the death penalty and the outcome of the novel, as on the debate of ideas and social hypocrisy.

In La piedra angular, Emilia Pardo Bazán established a tight connection between society and literature, without giving up the constant pursuit of the ideal of beauty in her writings. In her study of modern French literature, El Naturalismo (1911) Emilia Pardo Bazán pointed out French critic Brunetière's ideas on the importance of not isolating ethics from art, and at the same time not using art for utilitarian or moralising purposes. She was convinced that art should not only pursue formal beauty as an ideal, art for art's sake, but that it should also remain in touch with human beings. As Brunetière said, not everything is permissible in art. The painter or the poet is first and foremost a human being and has no right to act against "human society or to 'dehumanise' the souls". Brunetiere's moralism is not based on prohibition. This moral value stems from its focus on the importance of will and action. And acting by means of Literature is the main purpose. (Pardo Bazán 1911: 329).

From his point of view, according to the Naturalists, art should develop interest in what were not considered appropriate subjects for art the time. In doing so, art will leave its strict patterns and rules, but it will nevertheless achieve greatness. The independence or textual autonomy of Flaubert is, in short, a nonsense. Brunetière said that "the main duty of an artist is to question 
things, to expose problems and discuss issues", so, any play, a speech or a book are per se ethical deeds.

Therefore, if imitation of nature is the source of art and not its strict aim, Emilia Pardo Bazán - also following Brunetiere's ideas- pointed out that nature can or cannot be beautiful, but it does not necessarily have to be good (Pardo Bazán 1911: 329). To grasp nature is to grasp animality. Pardo Bazán’s investigations of the soul, of the most basic human instincts, and of human psychology encouraged her to write La piedra angular. At first, she was interested in the figure of the executioner who must carry out the death sentence, that is to say the one who kills in the name of justice and society. However, given the complexity of this issue, she could not avoid mentioning in her work all the controversies about capital punishment, the nature of the criminal and even the very nature of the executioner.

Although Emilia Pardo Bazán defined herself as an abolitionist, it was not the one and only position she advocated in La piedra angular. In fact, she mentions all the different approaches because to her that "kind of problems never appear alone, they are always accompanied by others that can have a powerful influence on them” (Pardo Bazán 1907). The biggest difficulty lay, as Rafael Altamira pointed out, "in turning a literary question into one of the greatest burning issues of the time". On top of all, this issue rests "on an intellectual crisis" as well as on "inherited prejudices" (Altamira 1892).

In order to do so, the writer reflects on the scientific progress recorded in criminal anthropology and its impact on forensic science. Criminality is the key word that bonds together all these aspects which were supported in the theories developed in Italy by Lombroso, Garrófalo and Ferri. They were disseminated in Spain by Rafael Salillas.

There are two ways to deal with crime in La piedra angular. On the one hand, an emotional approach - a crime which takes place in La Erbeda, close to Marineda. On the other hand, a legal approach which is more problematic because it is based on institutionalised crime. The executioner represents an aspect of crime established and performed by society. From these two perspectives, the writer introduced the ideas of crime, criminal, freedom of choice, determinism, and atavism.

She uses these ideas to tackle a number of social evils: poverty, illiteracy, brutality, domestic violence, gender abuse, alcohol addiction, social hypocrisy, and double standards of morality between men and women. In 1891, Emilia Pardo Bazán was convinced that the novel should become a social tool for the Spanish society. As I said before, Emilia Pardo Bazán connects Art with Nature. She writes about her own experience, from close observation and study. 
THION SORIANO-MOLLÁ

In La piedra angular the writer presented modern ideas through two main realistically depicted characters, the scientist doctor Moragas, and the executioner Juan Rojo, both having their real prototypes in the Galician society. She also created several secondary characters, such as the lawyers who live in the city of Marineda, more particularly Lucio Febrero. In the novel, action is quite limited. Juan Rojo goes to the doctor's once, as he is looking for help. However, for the writer it is a pretext to study the marginalised people who live in the poorest districts of Marineda, especially Juan Rojo and his son Telmo. They both are hypocritically condemned by society, because of Rojo's much despised occupation. However, the action stems from a crime of passion. This crime is based on real events which occurred in Valladolid - a murder committed by a woman and her lover. The victim was the woman's husband who was a drunkard and a quarrelsome man.

The arrest, the trial and the final sentence in the background allow Emilia Pardo Bazán to present in a simple way these abstract ideas and to depict the environment by means of naturalistic method. The novel's plot should have its outcome in the execution by garrotting of the criminal, carried out by Juan Rojo. However, Rojo keeps his promise and fails to do the job he is paid for. Moragas, the doctor, plays the role of a scientist fond of his experiment. Rojo, the executioner, is his guinea pig. Lucio Febrero, the lawyer, is the defender of the new trends in forensic science. The doctor, the executioner and the lawyer are the three key elements of the novel.

The omniscient narrator assembles from a critical and ironic perspective all the criminal theories, the more conservative and moralistic, defending the death penalty, as well as the progressive ones based on determinism, defending abolition of death penalty and proposing instead the redemption or rehabilitation of the convict.

From the very beginning of the novel, the reader meets Doctor Moragas in his surgery. Moragas opposes anthropological determinism and supports psychology. In fact, Emilia Pardo Bazán thought that there was no scientific proof of the validity of Lombroso's typologies. In spite of this, Lombroso's theories became popular because they were based on elements of truth, but truths mixed with hypotheses and, as such, simple and accessible to the public (Pardo Bazán 1909 and 1910). That is why Emilia Pardo Bazán provides the reader with a kind and positive description of her criminal despite Lombroso's typologies (Pardo Bazán 1891a: 108).

The criminal is described as tiny woman with delicate features and a pale complexion, with parted dark hair. And above all, she looks like an angel. Her attitude is meek and humble. "Why are the Civil guards arresting such an 
innocent creature? Can she possibly be a criminal?", thinks Doctor Moragas (Pardo Bazán 1891a: 108).

A stark example of the role of modern science is proposed when Doctor Moragas establishes his diagnosis about Juan Rojo. Doctor Moragas is not interested in classical medicine, based on physiology. He has a keener interest in psychiatry and studies his patients as a harmonious whole, taking into account their bodies and minds. When the doctor studies Juan Rojo's liver, he realises that his illness has mental causes. He thinks that if he can cure the bile, he will manage to alter his patient's behaviour as well. He was not born a natural criminal; he was legally forced to kill to make a living. His two main purposes were to redeem his condition as an executioner and to save the convicts. Doctor Moragas is, in fact, doctor Ramón Pérez Costales, the alter ego of Emilia Pardo Bazán's own doctor. She shared her liberal ideas with him. The novel is quite complex because the doctor is not a stock character. When dealing with criminality, Moragas' thoughts appear mixed with those of Cesar Silió, who is a lawyer, a close friend of Emilia Pardo Bazán, and, in the novel, the alter ego of Febrero. Moreover, Moragas, in the world of fiction, shared these ideas of redemption. This stresses the idea of perfectibility: one can always change one's behaviour and improve.

Contrary to the lawyer, Febrero is partially inspired by Silió. Emilia Pardo Bazán embodies the young lawyer who displays a detachment from redemption, because, as a matter of fact, he is a follower of Lombroso. This is remindful of the typologies of criminality and atavism. Thus, Emilia Pardo Bazán multiplies the different points of view and opinions about capital punishment.

The discussions among them are never theoretical, but are full of irony, mockery, puns and proverbs. This way of presenting belief in redemption as opposed to determinism, and reason as opposed to feelings, eases tension. Emilia Pardo Bazán tries to seduce the reader without oversimplifying her prose or lessening its quality. The novel is built on this kind of ironic oppositions. Making fun of one another and constantly making provocative comments. Each example is matched by a counter-example. Like the yin and the yang. An opinion supporting an idea immediately comes up against the opposite view.

All the characters have a peculiar psychology and are influenced by their own social, economic, and environmental background. The best example is Juan Rojo. A machine that kills, but also a man, a husband and a father - a person who thinks he deserves social respect because he is the ultimate representation of justice. Hence, Emilia Pardo Bazán shows that there is not just a one and only truth. The best example of this is the tertulia in the casino "La Amistad" ("friendship" in English). The casino is the name of the premises used by citizens to meet and discuss current affairs. In short, the tertulia is the act of meeting 
THION SORIANO-MOLLÁ

to chat. Among those who participate in the conversion, sits Arturo Cáñamo, whose nickname is " 7 gallows". He is a conservative lawyer who defends capital punishment. He argues for very strict laws and the extreme morality of good versus evil; there is also Lucio Febrero, the young and "anarchist" lawyer, who advocates for liberal and progressive ideas.

Emilia Pardo Bazán is a master of vivid and swift dialogues. Nobody uses long speeches to defend their ideas. They indirectly present their points of view by challenging their opponents' arguments.

The outcome of the novel is unexpected with a very typical Spanish attitude. With irony and black humour, we are invited to make fun of everything and everyone, but especially of ourselves. The novel ends in an improvised popular song that plays on the word "abolish" (Pardo Bazán 1891a: 171). Although Emilia Pardo Bazán, as we said before, shows different points of view, the reader can perceive a certain preference for the character of Doctor Moragas, the most humane of them all. In fact, he manages to convince Juan Rojo to stop executing criminals.

Yet Emilia Pardo Bazán also shows that there are no ultimate solutions. Doctor Moragas would never have imagined that Juan Rojo, instead of killing the others, would kill himself. In Emilia Pardo Bazán's universe, nobody is completely right, not even in a thesis novel. She neither imposes her own ideas, nor subordinates the novel to a single opinion. She even says: "I have never believed in redemption because our true nature will always persist". However, she also adds that: "capital punishment depresses me, because it's ugly, repulsive, reckless, as when you condemn an innocent person. And useless because there is no profit and least of all for the one who suffers the punishment" (Pardo Bazán 1891b: 93-94).

In La piedra angular, Emilia Pardo Bazán manages to create a universe which is not only plausible, but vibrant like a portrait of society. She succeeds in raising people's awareness on capital punishment and the new concept of forgiveness. Given the complexity of this topical issue, Emilia Pardo Bazán examines a wide range of ideas but never takes sides, because when dealing with this complex question, she underlines that emotion is stronger than reason, that there is no only one truth, and that above all human life deserves respect.

\section{Dolores Thion Soriano-Mollá}

dolores.thion@gmail.com

16, Rue Adolphe Moitié

44000 Nantes

FRANCE 
Emilia Pardo Bazán, an Ethical Writer

\section{Bibliography}

Altamira, R. 1892. Correo Literario. La piedra angular, novela de doña Emilia Pardo Bazán. - La Justicia, 2 de febrero.

Andrade, B. M. 1896. La antropología criminal y la novela naturalista, Madrid: Tipografía de Rivadenyra.

Etreros, M. 1993. Influjo de la narrativa rusa en doña Emilia Pardo Bazán. El ejemplo de La piedra angular. - Anales de Literatura Española, 9, 31-43.

Henn, D. 1991. Issues and individuals: Pardo Bazán’s La Piedra angular. - Forum for Modern Language Studies, 4, 358-369.

Maristany, L. 1973. El Gabinete del Doctor Lombroso. (Delincuencia y fin de siglo en España). Barcelona: Cuadernos Anagrama.

Oliver Olmo, P. 2008. La pena de muerte en España. Madrid: Síntesis.

Pardo Bazán, E. 1891a. La piedra angular. Madrid: Imprenta de A. Pérez Dubrull.

Pardo Bazán, E. 1891b. Juicios cortos. Un tratadista de derecho penal. - Nuevo Teatro Crítico, I, IV, 89-94.

Pardo Bazán, E. 1891c. Notas literarias. - Nuevo Teatro Crítico, I, IX, 95-96.

Pardo Bazán, E. 1907. La vida contemporánea.- La Ilustración Artística, 19-IV.

Pardo Bazán, E. 1909. La vida contemporánea.- La Ilustración Artística, 8-XI.

Pardo Bazán, E. 1910. La vida contemporánea.- La Ilustración Artística, 27-VI.

Pardo Bazán, E. 1911. La literatura moderna. El Naturalismo, Obras completas de Emilia Pardo Bazán, 41. Madrid: Renacimiento.

Pardo Bazán, E. 1989. La cuestión palpitante (1891). J. M. González Herrán, ed. Madrid: Anthropos, Universidad de Santiago de Compostela.

Silió Cortés, C. 1891. La crisis del derecho penal. Madrid: Fuentes y Capdeville.

Tarde, G. 1892. La Piedra Angular. - Archives de Antropologie criminelle, 7, 444-448.

Thion Soriano-Mollá, D. 2016. La Piedra angular de Emilia Pardo Bazán: fuentes e imágenes especulares de la sociedad. - D. Thion et ali., ed., Le Texte au miroir. Paris: L'Harmattan, 201-212.

Varela, J. L. 2001. Pardo Bazán: Epistolario a Giner de los Ríos (Continuación). Boletín de la Real Academia de la Historia, CXCVIII, 439-506.

Wyly Gilfoil, A. 1996-1997. The Criminal Mind and the Social Body: Pardo Bazán's La piedra angular. - Anales galdosianos, 31-32, 83-96. 